\title{
Actual distribution and present status of a threatened aquatic plant, Sagittaria aginashi (Alismataceae), in Korea
}

\author{
Takashi Shiga, Kazumasa Tsubota ${ }^{1}$ and Hyeok Jae Choi ${ }^{2 *}$ \\ Faculty of Education, Niigata University, Niigata 950-2181, Japan \\ ${ }^{1}$ Graduate School of Science and Technology, Niigata University, Niigata 950-2181, Japan \\ ${ }^{2}$ Department of Biology and Chemistry, Changwon National University, Changwon 51140, Korea \\ (Received 25 July 2017; Revised 8 September 2017; Accepted 22 September 2017)
}

\begin{abstract}
We evaluated the actual distribution, present status, and number of remnant individuals of Korean Sagittaria aginashi (Alismataceae) based on herbarium specimens and field surveys. We also reidentified Korean $S$. aginashi by analyzing sequences of the internal transcribed spacer (ITS) region. We found nine specimens of $S$. aginashi in herbaria from four localities housed at the Osaka Museum of Natural History (OSA) and at the Korea National Herbarium (KH). During our field research, we could not confirm the current statuses of two collection localities (Taereung and Ansan-si), though this was not the case for Ulsan-si. In addition, we found two new localities in Ulsan-si and Yangsan-si. These three remnant populations are distributed in wetlands in mountainous areas (elev. 480-740 m). With regard to the number of flowering and immature individuals in the three localities, there were $<50$ and $<2,000$, respectively, in total. ITS sequences demonstrated that the sequences of Korean and Japanese $S$. aginashi are uniform and distinct from other Sagittaria species. These results indicate that S. aginashi is a rare and threatened species in Korea. It should be listed as an endangered species on the Korean Red List and requires urgent protection by conservation programs, including the extensive surveys of other possible natural habitats.
\end{abstract}

Keywords: Genetic identification, ITS, Korea, Red List, Sagittaria aginashi

Aquatic macrophytes are an important ecological element in inland water ecosystems. However, because their general habitats are highly sensitive to environmental change caused by anthropogenic impact (such as eutrophication, water abstraction, sediment mining, shoreline reinforcement, and invasive alien species), massive diversity loss has occurred (Cronk and Fennessy, 2001; Akasaka et al., 2010; Kadono, 2014). To develop an optimum conservation program, it is necessary to correctly identify species and recognize their present status (Frankham et al., 2010). Taxonomic status must be accurately established to ensure that neither are endangered species denied protection nor is effort wasted on abundant species. Many aquatic macrophytes showing highly adaptive, phenotypic plasticity, and morphology among juvenile and adult plants often have highly different characteristics (Sculthorpe, 1967). It is occasionally difficult to identify aquatic plant species lacking taxonomic key characters based on only morphological features.
For aquatic macrophytes, taxonomic misidentification may lead to ignoring populations of threatened species requiring conservation programs. In addition, incorrect conservation effort may seriously affect natural populations.

The genus Sagittaria L. (Alismataceae) is a group of perennial, submerged to emergent aquatic plants, consisting of approximately 36 currently recognized species (Keener, 2005).

The distribution area of the genus includes Africa, Asia, Europe, and North and South America. In Korea, three native Sagittaria species have been identified (Kim and Choi, 2007; Lee, 2007): (1) S. aginashi Makino; (2) S. pygmaea Miq.; and (3) S. trifolia L. In Korea, S. trifolia is sometimes treated as a synonym of S. sagittifolia L. (Kim and Choi, 2007). However, S. sagittifolia is different from $S$. trifolia in having petals with a violet spot at the base and violet anthers (Keener, 2005). No such species occurs in Korea, and therefore, we do not treat Korean S. trifolia as a synonym of S. sagittifolia.

\footnotetext{
*Author for correspondence: hjchoi1975@changwon.ac.kr
} 
Sagittaria aginashi is a perennial emergent aquatic species, which is distributed in ponds, marshes, moors, and paddy fields in Korea and Japan (Kim and Choi, 2007; Lee, 2007; Kadono, 2014). In morphological traits of the emergent leaf and reproductive organs, $S$. aginashi is similar to $S$. trifolia, although $S$. aginashi is remarkable for the peculiarity that it has numerous small tubercles at the base within the vagina of petioles and no stolon (Makino, 1901; Kim and Choi, 2007; Kadono, 2014). For that reason specimens of $S$. aginashi lacking roots and the base of petioles have been often misidentified as S. trifolia (Shiga, unpubl. data). In these cases, DNA sequencing analysis is a powerful tool for identifying Sagittaria plants (Shiga et al., 2017).

In Japan, wetland destruction by human activity has led to the extinction of local populations of $S$. aginashi, and this species is categorized as a "near-threatened species" on the Japanese Red List (Ministry of the Environment Government of Japan, 2015). In Korea, S. aginashi is believed to be relatively common in almost all provinces (Shin et al., 1997) or in the eastern provinces (Gangwon-do, Gyeongsangbuk-do, and Gyeongsangnam-do) of the Korean peninsula (Kim and Choi, 2007). However, Choi (2000) has mapped this species in only one site of Gangwon-do. Recently, Oh et al. (2016) have published distributional maps of Korean plants based on specimen data, including $S$. aginashi, and the map revealed that the species may be extremely rare. Hence, detailed research into the actual distribution and present status of $S$. aginashi based on many specimens, including Japanese herbarium material and natural habitats, is needed to conserve this species.

The goal of the present study was to (1) estimate the actual distribution of $S$. aginashi, (2) evaluate the present status and number of individuals remaining in natural habitats of the species, and (3) re-identify Korean $S$. aginashi by analyzing sequences of the internal transcribed spacer (ITS) region. We also preliminary discuss the genetic relationships among related species.

\section{Materials and Methods}

\section{Herbarium and field research}

We surveyed herbarium specimens of $S$. aginashi collected in Korea and Japan deposited at the Korea National Herbarium (KH), the Kumamoto Prefecture Museum Network Center, Kobe University, Kyoto University (KYO), the National Museum of Nature and Science (TNS), Niigata University, the Osaka Museum of Natural History (OSA), and the University of Tokyo (TI). In KH, we investigated all specimens of the genus Sagittaria.
In September 2016, we also investigated the current population size and habitat conditions of $S$. aginashi in three remnant populations (Table 1). We counted the number of flowering and immature individuals.

\section{ITS region analysis}

To genetically identify the Korean $S$. aginashi, we conducted genetic analyses using the DNA sequence of the ITS regions (including ITS1, ITS2, and 5.8S rRNA regions) of nuclear ribosomal DNA. One plant was collected from each of the three remnant populations of $S$. aginashi and two herbarium specimens collected from Ansan-si (KH1269331) and Jeju Island (KH1058867) were surveyed (Table 1). The following six GenBank sequences were added to the DNA sequence dataset: $S$. aginashi (LC169553) collected in Japan, $S$. lichuanensis (AY395992), S. potamogetifolia (AY395990), S. pygmaea (LC169556), S. tengtsungensis (AY395994), and $S$. trifolia (LC169551) (Table 1). Sequence similarities among sequence types were calculated based on the ratio of the number of matched sequences among the number of sequences to be compared.

Total DNA was extracted from $50-100 \mathrm{mg}$ of dried leaves of each specimen using the cetyltrimethylammonium bromide method (Milligan, 1992). Relevant portions of the ITS region were amplified from total genomic DNA by the polymerase chain reaction (PCR) using thermostable DNA polymerase (EmeraldAmp PCR Master Mix, Takara Bio Inc., Tokyo, Japan) and primers designed by White et al. (1990), namely ITS5 (5'-GGAAGTAAAAGTCGTAACAAGG-3') and ITS4 (5'-TCCTCCGCTTATTGATATGC-3'). PCR was performed using a TaKaRa PCR Thermal Cycler TP650 Standard (Takara Bio Inc.) programmed for $4 \mathrm{~min}$ at $94^{\circ} \mathrm{C}, 35$ cycles of $1 \mathrm{~min}$ at $94^{\circ} \mathrm{C}$ (denaturation), $1 \mathrm{~min}$ at $53^{\circ} \mathrm{C}$ (annealing), and $1 \mathrm{~min}$ $30 \mathrm{~s}$ at $72^{\circ} \mathrm{C}$ (extension), with a final step of $7 \mathrm{~min}$ at $72^{\circ} \mathrm{C}$. Direct sequencing of purified PCR products was performed using the BigDye Terminator Cycle Sequencing Kit (Applied Biosystems, Foster City, CA, USA) with the same primers on the ABI Prism 3130 automated sequencer (Applied Biosystems).

\section{Results}

\section{Herbarium and field research}

In our herbarium search, we found nine specimens of $S$. aginashi from four localities housed in OSA and KH (Fig. 1): Taereung (OSA), Ansan-si (KH), Ulsan-si (KH), and Jeju Island $(\mathrm{KH})$. In $\mathrm{KH}$, there were seven specimens of $S$. aginashi and many narrow-leaved $S$. trifolia had been misidentified as S. aginashi. 
In our field research, we surveyed natural populations of $S$. aginashi based on the specimens' locality data. We could not confirm the current status of two collection localities (Taereung and Ansan-si), but only that of Ulsan-si (Mujechi-neup). We also found two new localities of S. aginashi in Ulsan-si (Doltimineup) and Yangsan-si (Mt. Sinbul-san). These three remnant populations are found in wetlands in mountainous areas (alt. 480-740 m) (Fig. 2, Table 1), and details are as follows. In case of locality in Jeju Island, we have not accessed in this study.

Firstly, in Mujechi-neup, the numbers of flowering mature and immature plants of $S$. aginashi were $<10$ and 100-1,000, respectively (Table 1 ). The distribution area was ca. $160 \mathrm{~m}^{2}$ and the total wetland area was $13,000 \mathrm{~m}^{2}$. Sagittaria aginashi plants are sympatric with Utricularia bifida L., U. caerulea L., Isachne globosa (Thunb.) Kuntze, Miscanthus sinensis Andersson, and juvenile Alnus japonica (Thunb.) Steud. Secondly, in Doltimi-neup, the numbers of flowering mature and immature plants were 20-30 and 50-100, respectively (Table 1). Sagittaria aginashi was distributed in an area of ca. $130 \mathrm{~m}^{2}$ and the total wetland area was $400 \mathrm{~m}^{2}$. The species are sympatric with Scirpus wichurae Boeck., Schoenoplectiella

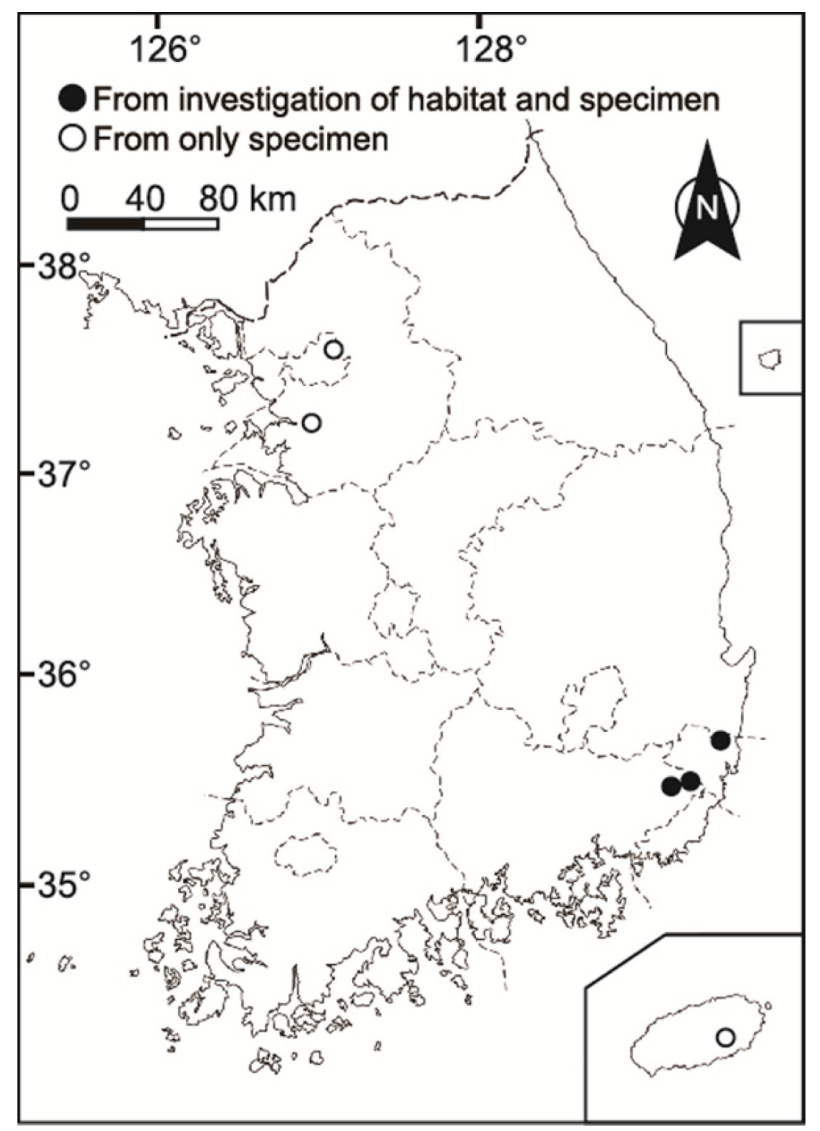

Fig. 1. Distribution of Sagittaria aginashi Makino in Korea. hotarui (Ohwi) J. D. Jung et H. K. Choi, and Saussurea pulchella (Fisch. ex Hornem.) Fisch. Finally, in Mt. Sinbulsan, the numbers of flowering mature and immature plants were $<10$ and 100-1,000, respectively (Table 1 ). The species that are sympatric with $S$. aginashi were $M$. sinensis and $S$. wichurae. The distribution area of $S$. aginashi and the total wetland area were ca. $290 \mathrm{~m}^{2}$ and $11,000 \mathrm{~m}^{2}$, respectively.

\section{Genetic identification and genetic variation}

Among the DNA sequences of the ITS region (670-677 bp) from 11 samples of genus Sagittaria, six sequence types (AF) were detected, distinguishable by 42 single nucleotide polymorphisms and five insertions/deletions (Table 2). The sequences of all $S$. aginashi from the three extant populations and the two herbarium specimens collected from Korea (Ansan-si and Jeju Island), as well as from GenBank data based on Japanese samples, were identical (sequence type A) (Table 1). Furthermore, the other sequence types each corresponded to a different species (sequence type B: $S$. tengtsungensis, C: S. lichuanensis, D: S. pygmaea, E: S. potamogetifolia, F: $S$. trifolia). The sequence-similarities between $S$. aginashi (sequence type A) and the other five species were $99.56 \%$, $99.41 \%, 98.97 \%, 96.76 \%$, and $95.58 \%$ for $S$. tengtsungensis, S. lichuanensis, S. pygmaea, S. potamogetifolia, and S. trifolia, respectively (Table 2 ).

\section{Discussion}

Sagittaria aginashi is remarkably peculiar because of the following characteristics: obtuse apex of basal lobes of sagittate leaves (Fig. 2F), small numerous tubercles at the base within the vagina of petioles (Fig. 2G), and no stolon (Fig. 2I) (Makino, 1901; Kadono, 2014). However, almost all specimens identified as $S$. aginashi did not have these key characters ( $\mathrm{T}$. Shiga, pers. obs.). Based on the Korean literature (e.g., Shin et al., 1997; Choi, 2000; Lee, 2003; Kim and Choi, 2007; Lee, 2007), S. aginashi probably have not been identified clearly in Korea. In fact, the photographs of S. aginashi in Lee (2003) and Lee (2007) are actually those of S. trifolia.

Sagittaria aginashi has sometimes been treated taxonomically as the same as S. trifolia (Keener, 2005). The ITS sequences distinguish the species of the genus Sagittaria and demonstrate that the sequences of $S$. aginashi are clearly different from those of $S$. trifolia (Table 1). We conclude that $S$. aginashi is rare, but clearly is distributed in Korea. We confirm that the ITS sequences of $S$. aginashi are uniform in the current preliminary genetic study (Tables 1,2 ). To clarify the historical biogeography of this species, further genetic 

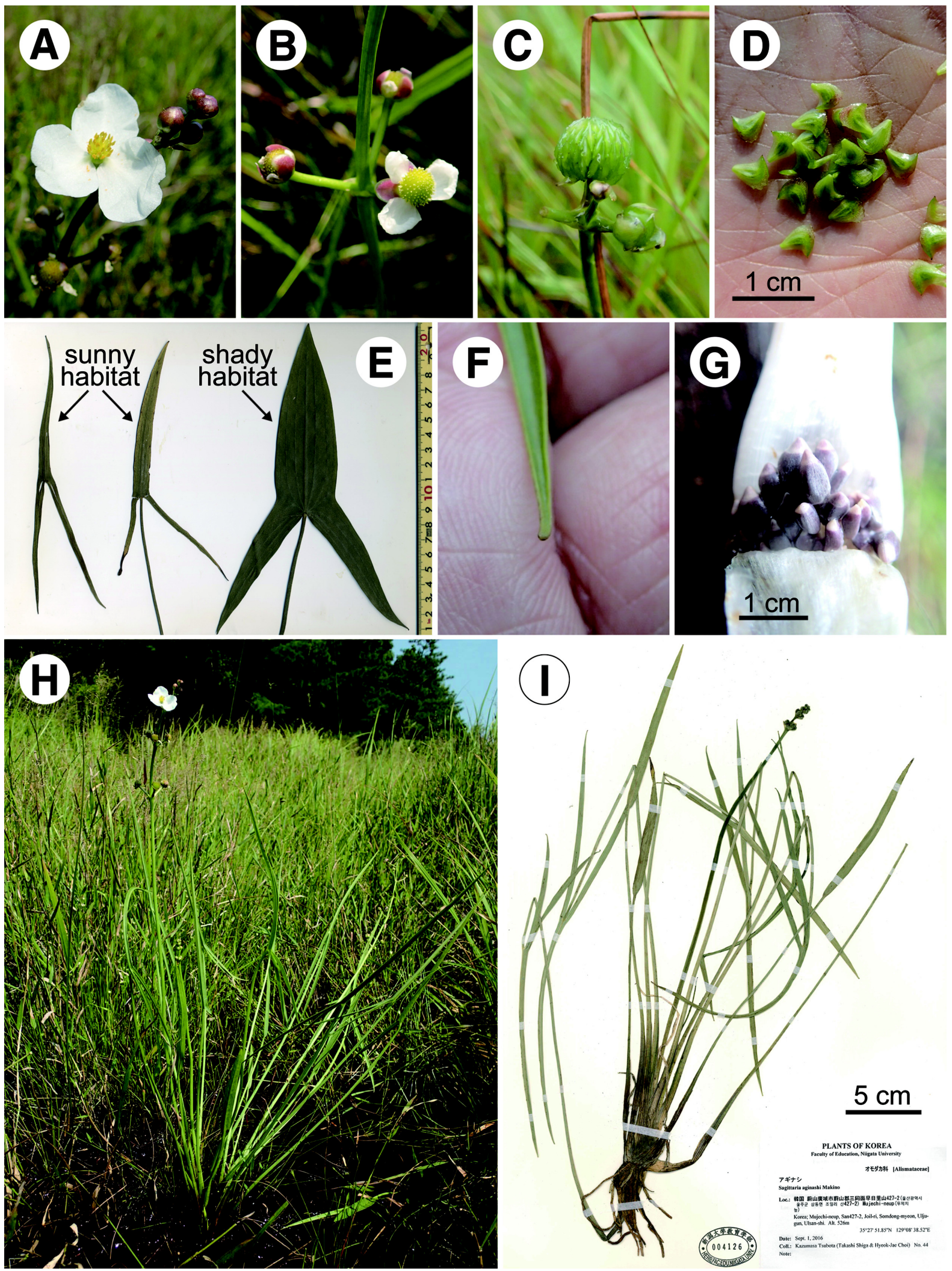

Fig. 2. Sagittaria aginashi Makino from Korea. A. Staminate flower. B. Small, closed pistillate flower. C, D. Fruits. E. Morphological variation of the leaf. F. Apex of basal lobes of sagittate leaves. G. Small tubercles in axil. H. S. aginashi in its habitat. I. The specimen from H (Tsubota et al. 44). 
Table 1. A list of sampling localities and present status of Sagittaria aginashi. Accession numbers of internal transcribed spacer (ITS) sequences are also shown.

\begin{tabular}{|c|c|c|c|c|c|c|c|c|c|c|c|}
\hline Taxon & Locality & Latitude & Longitude & $\begin{array}{l}\text { Elevation } \\
\quad(\mathrm{m})\end{array}$ & $\begin{array}{l}\text { No. of } \\
\text { flowering } \\
\text { plants }\end{array}$ & $\begin{array}{c}\text { No. of } \\
\text { immature } \\
\text { plants }\end{array}$ & $\begin{array}{l}\text { Distribution } \\
\text { range }\left(\mathrm{m}^{2}\right)\end{array}$ & $\begin{array}{l}\text { Wetland size } \\
\qquad\left(\mathrm{m}^{2}\right)\end{array}$ & Accession no. & $\begin{array}{l}\text { Sequence } \\
\text { type }\end{array}$ & Voucher \\
\hline S. aginashi & $\begin{array}{l}\text { KOREA: Mujechi-neup, } \\
\text { Ulju-gun, Ulsan-si }\end{array}$ & $35^{\circ} 27^{\prime} \mathrm{N}$ & $129^{\circ} 08^{\prime} \mathrm{E}$ & 530 & $1-10$ & $100-1,000$ & 160 & 13,000 & LC278398 & A & $\begin{array}{l}\text { Tsubota et al. } 44 \\
\text { (NGU4126) }\end{array}$ \\
\hline S. aginashi & $\begin{array}{l}\text { KOREA: Doltimi-neup, } \\
\text { Buk-gu, Ulsan-si }\end{array}$ & $35^{\circ} 40^{\prime} \mathrm{N}$ & $129^{\circ} 22^{\prime} \mathrm{E}$ & 480 & $20-30$ & $50-100$ & 130 & 400 & LC278399 & A & $\begin{array}{l}\text { Tsubota et al. } 50 \\
\text { (NGU4127) }\end{array}$ \\
\hline S. aginashi & $\begin{array}{l}\text { KOREA: Mt. Sinbul-san, } \\
\text { Yangsan-si, } \\
\text { Gyeongsangnam Prov. }\end{array}$ & $35^{\circ} 25^{\prime} \mathrm{N}$ & $129^{\circ} 00^{\prime} \mathrm{E}$ & 740 & $1-10$ & $100-1,000$ & 290 & 11,000 & LC278400 & A & $\begin{array}{l}\text { Tsubota et al. } 54 \\
\text { (NGU4128) }\end{array}$ \\
\hline S. aginashi & $\begin{array}{l}\text { KOREA: Sangnok-gu, } \\
\text { Ansan-si, Gyeonggi Prov. }\end{array}$ & $37^{\circ} 17^{\prime} \mathrm{N}$ & $126^{\circ} 55^{\prime} \mathrm{E}$ & 80 & - & - & - & - & LC278401 & A & $\begin{array}{l}\text { Jeon } 91244 \\
(\mathrm{KH} 1269331)\end{array}$ \\
\hline S. aginashi & $\begin{array}{l}\text { KOREA: Namwon-eup, } \\
\text { Seogwipo-si, Jeju Prov. }\end{array}$ & $33^{\circ} 21^{\prime} \mathrm{N}$ & $126^{\circ} 41^{\prime} \mathrm{E}$ & & - & - & - & - & LC278402 & A & $\begin{array}{c}\text { Kang s.n. } \\
\text { (KH1058867) }\end{array}$ \\
\hline S. aginashi & $\begin{array}{l}\text { JAPAN: Joetsu-shi, } \\
\text { Niigata Pref. }\end{array}$ & $37^{\circ} 09^{\prime} \mathrm{N}$ & $138^{\circ} 21^{\prime} \mathrm{E}$ & 20 & - & - & - & - & LC169553 & A & $\begin{array}{l}\text { Shiga } 7518 \\
\text { (NGU298) }\end{array}$ \\
\hline S. tengtsungensis & CHINA & & & & - & - & - & - & AY395994 & B & \\
\hline S. lichuanesis & CHINA & & & & - & - & - & - & AY395992 & $\mathrm{C}$ & \\
\hline S. pygmaea & $\begin{array}{l}\text { JAPAN: Takatsuki-shi, } \\
\text { Osaka Pref. }\end{array}$ & $34^{\circ} 53^{\prime} \mathrm{N}$ & $135^{\circ} 35^{\prime} \mathrm{E}$ & $40-50$ & - & - & - & - & LC169556 & $\mathrm{D}$ & $\begin{array}{l}\text { Shiga } 9070 \\
(\mathrm{NGU} 3012)\end{array}$ \\
\hline S. potamogetifolia & CHINA & & & & - & - & - & - & AY395990 & $\mathrm{E}$ & \\
\hline S. trifolia & $\begin{array}{l}\text { JAPAN: Awashimaura-mura, } \\
\text { Niigata Pref. }\end{array}$ & $38^{\circ} 27^{\prime} \mathrm{N}$ & $139^{\circ} 14^{\prime} \mathrm{E}$ & $50 ? 60$ & - & - & - & - & LC169551 & $\mathrm{F}$ & $\begin{array}{l}\text { Watanabe } 69 \\
\text { (NGU308) }\end{array}$ \\
\hline
\end{tabular}


research is required based on samples from the entire distributional range using multiple polymorphic markers.

In Korea, S. aginashi often has not been distinguished taxonomically with narrow-leaved $S$. trifolia and is believed to be a relatively common species. Although we have not surveyed on habitats of Jeju Island, we show that the number of populations of $S$. aginashi is quite low and that population sizes are extremely small in Korea (Fig. 1, Table 1). The lowland populations of the species may have become extinct mainly by human disturbance. The total number of flowering individuals in the three localities is $<50$, whereas that of immature individuals is $<2,000$ (Table 1). The effective population sizes of Korean $S$. aginashi may be quite small. The present status of $S$. aginashi indicates that this species should be listed as an endangered species in the Korean Red List and requires urgent protection by conservation programs including the extensive surveys on its additional natural habitats. Because $S$. aginashi reproduces asexually by numerous tubercles, intra-population genetic diversity may be at quite a low level. An evaluation of the genetic diversity using polymorphic markers, such as microsatellite markers, is needed to formulate an appropriate conservation program.

Furthermore, S. aginashi (sequence type A) is closely related to the Chinese endemic species $S$. tengtsungensis (sequence type B) and S. lichuanensis (sequence type C) (Table 2). The genetic diversity and genetic relationships among Chinese endemic Sagittaria species including $S$. tengtsungensis, $S$. lichuanensis, and $S$. potamogetifolia have been investigated well using multiple genetic markers (Du et al., 1998; Keener, 2005; Chen et al., 2012; Liao et al., 2016). Liao et al. (2016) revealed that $S$. tengtsungensis, S. lichuanensis, S. potamogetifolia, and $S$. pygmaea form a monophyletic group and that $S$. lichuanensis, consisting of many sequence types, is a genetically polymorphic species. These species, except for $S$. pygmaea, are distinguishable from other Sagittaria species by forming numerous tubercles at the base of the petiole (Chen et al., 1984; Chen, 1989; Wang and Chen, 1996; Wang et al., 2010). To clarify the phylogenetic relationships and taxonomic

Table 2. Six sequence types distinguished by single nucleotide polymorphisms and insertion/deletions of internal transcribed spacers (ITS 1 and 2) and 5.8S rRNA regions in 11 samples of genus Sagittaria collected in Korea, Japan, and China. The numbers in parentheses after the type name indicate the number of samples analyzed.

\begin{tabular}{|c|c|c|c|c|c|c|c|c|c|c|c|c|c|c|c|c|c|c|c|c|c|c|c|c|c|}
\hline \multirow{4}{*}{$\begin{array}{c}\text { Sequence } \\
\text { type }\end{array}$} & \multicolumn{24}{|c|}{ ITS1 } & \multirow{2}{*}{$\frac{5.8 \mathrm{~S}}{3}$} \\
\hline & & & & & & & & 1 & 1 & 1 & 1 & 1 & 1 & 1 & 1 & 1 & 2 & 2 & 2 & 2 & 2 & 2 & 2 & 2 & \\
\hline & & 1 & 2 & 5 & 6 & 6 & 6 & 1 & 1 & 1 & 2 & 2 & 5 & 7 & 8 & 8 & 0 & 0 & 3 & 5 & 5 & 5 & 5 & 5 & 2 \\
\hline & 1 & 3 & 0 & 1 & 2 & 3 & 7 & 1 & 2 & 5 & 0 & 8 & 4 & 3 & 3 & 9 & 2 & 3 & 0 & 0 & 5 & 6 & 7 & 8 & 9 \\
\hline $\mathrm{A}(6)$ & $\mathrm{C}$ & $\mathrm{T}$ & $\mathrm{C}$ & $\mathrm{T}$ & $\mathrm{C}$ & $\mathrm{T}$ & G & $\mathrm{C}$ & $\mathrm{C}$ & A & $\mathrm{T}$ & $\mathrm{C}$ & - & $\mathrm{T}$ & $\mathrm{T}$ & $\mathrm{C}$ & $\mathrm{G}$ & $\mathrm{C}$ & $\mathrm{T}$ & A & - & - & - & - & A \\
\hline $\mathrm{B}(1)$ & $\mathrm{C}$ & $\mathrm{T}$ & $\mathrm{C}$ & $\mathrm{T}$ & $\mathrm{C}$ & G & G & $\mathrm{C}$ & $\mathrm{C}$ & A & $\mathrm{T}$ & $\mathrm{C}$ & - & $\mathrm{T}$ & $\mathrm{T}$ & $\mathrm{C}$ & $\mathrm{G}$ & $\mathrm{C}$ & $\mathrm{T}$ & A & - & - & - & - & A \\
\hline$C(1)$ & $\mathrm{C}$ & $\mathrm{T}$ & $\mathrm{C}$ & $\mathrm{T}$ & $\mathrm{C}$ & G & G & $\mathrm{C}$ & $\mathrm{C}$ & A & $\mathrm{T}$ & $\mathrm{T}$ & - & $\mathrm{T}$ & $\mathrm{T}$ & $\mathrm{C}$ & $\mathrm{G}$ & $\mathrm{C}$ & $\mathrm{T}$ & A & - & - & - & - & A \\
\hline $\mathrm{D}(1)$ & $\mathrm{C}$ & $\mathrm{T}$ & $\mathrm{C}$ & $\mathrm{T}$ & $\mathrm{C}$ & G & G & $\mathrm{C}$ & $\mathrm{C}$ & G & A & $\mathrm{C}$ & - & $\mathrm{T}$ & A & $\mathrm{C}$ & $\mathrm{G}$ & $\mathrm{C}$ & $\mathrm{C}$ & A & - & - & - & - & A \\
\hline $\mathrm{E}(1)$ & $\mathrm{T}$ & $\mathrm{T}$ & $\mathrm{C}$ & $\mathrm{T}$ & $\mathrm{T}$ & G & G & A & $\mathrm{T}$ & A & $\mathrm{T}$ & $\mathrm{C}$ & A & $\mathrm{T}$ & A & $\mathrm{C}$ & $\mathrm{G}$ & $\mathrm{C}$ & $\mathrm{T}$ & A & $\mathrm{T}$ & A & $\mathrm{T}$ & A & A \\
\hline $\mathrm{F}(1)$ & $\mathrm{C}$ & $\mathrm{C}$ & A & $\mathrm{C}$ & $\mathrm{C}$ & G & $\mathrm{C}$ & $\mathrm{C}$ & $\mathrm{C}$ & $\mathrm{G}$ & $\mathrm{T}$ & $\mathrm{C}$ & - & $\mathrm{C}$ & A & $\mathrm{T}$ & A & $\mathrm{T}$ & $\mathrm{T}$ & $\mathrm{G}$ & - & - & - & - & $\mathrm{T}$ \\
\hline
\end{tabular}

Table 2. Continued.

\begin{tabular}{ccccccccccccccccccccccccccccccccc}
\hline \hline & & & & & 4 & 4 & 4 & 4 & 5 & 5 & 5 & 5 & 5 & 5 & 5 & 5 & 5 & 5 & 5 & 5 & 5 & 5 & 5 & 5 & 5 & 6 & 6 & 6 & 6 & 6 & 6 & 6 \\
Sequence & 3 & 4 & 6 & 9 & 0 & 2 & 2 & 3 & 4 & 5 & 5 & 6 & 7 & 7 & 7 & 7 & 7 & 8 & 8 & 8 & 9 & 0 & 2 & 2 & 2 & 4 & 5 & 6 \\
type & 9 & 1 & 4 & 2 & 9 & 3 & 4 & 2 & 4 & 0 & 1 & 9 & 2 & 5 & 6 & 7 & 9 & 2 & 3 & 4 & 8 & 3 & 2 & 4 & 5 & 1 & 6 & 4 \\
\hline A(6) & T & G & T & T & G & G & T & T & - & G & C & A & A & - & - & C & C & G & G & G & T & T & T & C & G & C & T & A \\
B(1) & T & G & T & T & G & G & T & C & - & G & C & A & A & - & - & C & C & G & G & G & C & T & T & C & G & C & T & A \\
C(1) & T & G & T & T & G & G & T & C & - & G & C & A & G & - & - & C & C & G & G & G & T & T & T & C & G & C & T & A \\
D(1) & T & G & T & G & G & G & T & C & - & G & C & A & A & - & - & C & C & G & G & G & T & T & T & G & G & C & T & A \\
E(1) & T & A & T & T & T & G & T & C & T & A & T & T & A & - & - & C & C & G & G & G & T & T & C & G & A & C & C & A \\
F(1) & C & G & C & T & G & T & G & C & - & G & C & G & A & G & G & A & A & - & - & - & T & C & T & G & G & A & T & G \\
\hline
\end{tabular}


status of $S$. aginashi among these Chinese endemic species, phylogenetic studies based on the DNA sequences of multiple loci and detailed morphological studies are needed.

\section{Taxonomic treatment}

Sagittaria aginashi Makino, Bot. Mag. (Tokyo) 15: 104, 1901; S. sagittifolia L. var. aginashi Makino, Bot. Mag. (Tokyo) 6: 49, 1892. —TYPE: Japan, Honshu, Prov. Iwaki (Fukushima Prefecture), Maniwa near Sakamoto in Watarigori, 17 Aug 1890, Makino s.n. [Lectotype designated by Tanaka (2005): MAK77766!] (Fig. 2).

Description: Perennial, glabrous herbs, 30-70 cm tall (29$150 \mathrm{~cm}$-morphological variation ranges including Japanese plants indicated in parentheses); rhizomes erect, thick, densely rooting; stolon absent; corm absent; numerous tubercles on the inside of the sheath at base; tubercles $0.4-0.8(0.3-1.0) \mathrm{cm}$ long, $0.2-0.4(0.2-0.7) \mathrm{cm}$ wide. Leaves radical, fasciculate, erect, strongly nervate, petiolate; petioles $23-46(23-83) \mathrm{cm}$ long; blades lanceolate to linear or sagittate; leaves from spring to early summer and in juvenile plants lanceolate to linear without basal (lateral) lobes; basal lobes of sagittate leaves 712 (5-25) cm long; remainder of blade (middle lobe) 6-12 (420) $\mathrm{cm}$ long, 0.6-4.5 (0.6-9.8) cm wide; apex of basal lobes obtuse; latex seeping from scratches. Scapes erect, emersed, $30-71(29-152) \mathrm{cm}$, taller than the leaves; inflorescence usually paniculate, in 4 to many whorls of ( 2 or) 3 flowers, lowest whorl rarely branched; female flowers on lowest 1 (or 2) whorls; bracteoles free or connate toward the base, $0.5-1.0 \mathrm{~cm}$ long. Flowers unisexual, the female flower below and male one above. Sepals 3, ovate to oblong, obtuse, entire, light green shaded with red, persistent, ca. 5-8 mm long. Petals 3, suborbicular, 8-13 mm long. Stamens 23 (18-24); anthers yellow. Ovaries numerous, apocarpous, crowded in a spherical head. Achenes 15-17 mm long, narrowly winged, with a short beak. Flower and fruit Jul-Aug. $2 n=22$ (Harada, 1956).

Korean name: Bo-pul.

Distribution and habitat: Japan (Hokkaido, Tohoku, Kanto, Chubu, Kinki, Chugoku, Shikoku, Kyushu) and Korea (Gyeonggi, Gyeongnam, Jeju) (Fig. 1). In ponds, lakes, marshes, moors, and paddy fields.

Specimens examined: KOREA. Gyeonggi: Taereung, 8 Sep 1940, H-D. Jang 1135, 1142 (OSA227615, 227616); Ansansi, Sangnok-gu, 17 Sep 2009, E. S. Jeon 91244 (KH1269331). Ulsan-si: Ulju-gun, Somdong-myeon, Mujechi-neup, 17 Aug 2006, S. H. Park \& G. H. Nam 61296 (KH1120514-1120516); 1 Sep 2016, K. Tsubota et al. 44, 45 (Niigata University = NGU4126, 4491); Buk-gu, Maegok-dong, Doltimi-neup, 1 Sep
2016, K. Tsubota et al. 46-52 (NGU4127, 4492-4497). Gyeongnam: Yangsan-si, Wondong-myeon, Dae-ri, 2 Sep 2016, K. Tsubota et al. 53-57 (NGU4128, 4498-4501). Jeju: Seogwipo-si, Namwon-eup, 23 Aug 2001, Y. J. Kang s.n. (KH1058229, 1058866, 1058867).

JAPAN. Hokkaido Pref.: Tomakomai-shi, 14 Aug 2016, K. Tsubota et al. 34-38 (NGU4124, 4484-4487). Aomori Pref.: Higashidori-mura, 5 Aug 2016, S. Nemoto 3369 (NGU4123); Goshogawara-shi, 14 Sep 2016, K. Tsubota \& A. Matsumoto 70-72 (NGU4132, 4512, 4513). Akita Pref.: Mitane-cho, 15 Sep 2016, K. Tsubota 73-77 (NGU4133, 4514-4517). Iwate Pref.: Takizawa-shi, 13 Sep 2016, K. Tsubota \& T. Shiga 6569, 83 (NGU4131, 4507-4511); Isawa-cho, 1 Sep 1985, $Y$. Kadono 770 (Kobe University). Miyagi Pref.: Osaki-shi, 12 Sep 2016, K. Tsubota \& T. Shiga 62-64 (NGU4130, 4505, 4506). Fukushima Pref.: Kitashiobara-mura, 27 Sep 2016, $K$. Tsubota \& K. Shutoh 81, 82 (NGU4135, 4520); Tamakawamura, 1 Aug 2016, K. Tsubota et al. 27-29 (NGU4121, 4479, 4480); Iwaki-shi, 1 Aug 2016, K. Tsubota et al. 24-26 (NGU4122, 4477, 4478). Tochigi Pref.: Nasukarasuyama-shi, 29 Jul 2016, K. Tsubota et al. 17-22 (NGU4118-4120, 44744476); Hongo-mura, 15 Aug 1953, K. Ogawa s.n. (OSA). Niigata Pref.: Sado-shi, 16 Jul 2016, K. Tsubota 5-9 (NGU4117, 4470-4473); Gosen-shi, 25 May 2016, K. Tsubota 1-3 (NGU4466-4468), 7 Sep 2016, K. Tsubota 58-61 (NGU4129, 4502, 4504); Sanjo-shi, 25 May 2016, K. Tsubota 4 (NGU4469); Joetsu-shi, 25 Sep 2016, K. Tsubota et al. 7880 (NGU4134, 4518, 4519), 9 Sep 2013, T. Shiga 7518 (NGU297, 298, 300), 24 Sep 2008, T. Shiga \& S. Takebayashi 6388 (OSA239165). Nagano Pref.: Hakuba-mura, 19 Aug 1975, K. Seto 21626, 21627 (OSA28426, 28427). Aichi Pref.: Toyoake-shi, 8 Sep 1968, S. Hamashima s.n. (OSA185419). Shiga Pref.: Koka-cho, 29 Aug 2001, K. Seto 55464 (OSA161116); Makino-cho, 30 Aug 1966, T. Kodama 10864 (OSA3472). Kyoto Pref.: Miyazu-shi, 14 Jun 2001, S. Fujii et al. 8624 (OSA206370), 15 Sep 1995, K. Seto 44829 (OSA101400-101402). Nara Pref.: 9 Aug 1948, M. Hutoh 1084 (OSA198806); Nara-shi, 26 Sep 1965, K. Seto 14928 (OSA1743), 9 Jun 1963, K. Seto 12293 (OSA198809); Tenrishi, 3 Sep 1999, N. Morimoto 4482 (OSA244026), 26 Sep 1997, K. Seto 48119 (OSA104917); Kitakatsuragi-gun, 1 Aug 1951, T. Kodama s.n. (OSA198808); Soni-mura, 24 Aug 2011, N. Morimoto 11924 (OSA188309); Tsukigase-mura, 14 Jun 2003, K. Seto 59208 (OSA165643). Osaka Pref.: Izumi-shi, 8 Sep 1985, C. Shimizu s.n. (OSA204544), 13 Oct 1983, C. Shimizu s.n. (OSA204561); Sakai-shi, 20 Aug 1933, O. Kishimoto 1083 (OSA); Shijonawate-shi, 26 Aug 1999, M. Tanaka s.n. (OSA148585), Aug 1931, Kira s.n. (OSA204041); 
Shijonawate-cho, 24 Sep 1963, K. Seto 12974 (OSA); 24 Sep 1963, M. Kuwashima s.n. (OSA); Senpoku-gun, 22 Sep 1960, K. Seto 10407 (OSA58620). Mie Pref.: Shimagahara-mura, 23 Sep 1999, K. Seto 51559 (OSA156483); Yokkaichi-shi, 2 Aug 1951, N. Yasui s.n. (OSA); 13 Aug 1950, N. Yasui s.n. (OSA); Ueno-shi, 21 Aug 2003, K. Seto 59676 (OSA), 3 Oct 1999, S. Fujii 7182 (OSA201287); Nabari-shi, 7 Aug 1992, K. Seto 38848-38851 (OSA93981-93984). Hyogo Pref.: Kumobemura, 1 Jul 1928, S. Yonezawa s.n. (OSA180470); Takarazukashi, 13 Sep 1998, K. Seto 49823 (OSA152575); 14 Sep 1997, K. Seto 48062 (OSA150060). Wakayama Pref.: Wakayamashi, 19 Sep 2000, S. Fujii 8278 (OSA203436); Ono-shi, 17 May 2016, Y. Kadono s.n. (NGU4481-4483), 30 Sep 1998, T. Fujii 10508 (OSA210073); Kato-shi, 11 Oct 2014, T. Shiga 8299 (NGU2775). Hiroshima Pref.: Higashihiroshima-shi, 22 Sep 2013, T. Shiga 7594 (NGU299). Kagawa Pref.: Mannoucho, 19 Aug 2016, T. Shiga et al. s.n. (NGU4125, 4488-4490). Kumamoto Pref.: Arao-shi, 10 Aug 1934, H. Arao 692 (Herb. of Kumamoto Pref. Matsubase Store House = NB, 21-000681), 17 Oct 1933, H. Arao 694, 695 (NB21-000683, 000684), 18 Sep 1932, H. Arao 696, 697 (NB21-000685, 000686); Minamioguni-machi, 18 Jul 1993, T. Maeda s.n. (NB21114265), H. Nobukuni 4416 (NB21-006292); Ashikita, 1953, M. Maeda s.n. (NB21-050593); Kuma-mura, 16 Aug 1917, S. Tokunaga s.n. (NB21-050597); Aso-shi, 30 Sep 1906, H. Kozuma s.n. (NB21-050594).

\section{Key to the Sagittaria species in Korea}

1. Leaves linear to spatulate; carpellate flowers sessile ….. S. pygmaea 올미

1. Leaves sagittate; carpellate flowers subsessile or pedicellate.

2. Stolon absent; tubercles present in leaf axils; apex of basal lobes obtuse; basal lobes usually shorter than the middle lobe; scapes taller than the leaves ……....

S. aginashi 보풀

2. Stolons with terminal tubers; tubercle absent; apex of basal lobes acute; basal lobes usually longer than the middle lobe; scapes usually shorter than the leaves . S. trifolia 벗풀

\section{Acknowledgments}

We are grateful to the following people for their help with sampling plant materials: Dr. Chang Ho Shin, Dr. Kyeong Choi and Mrs. Gae Sun Jang (KH), Dr. Akiko Shimizu (TI), Dr. Atsushi Ebihara (TNS), Dr. Hidetoshi Nagamasu (KYO), Dr.
Masahiro Hasegawa (OSA), Mr. Masashi Yokogawa (OSA), Dr. Tetsuya Maeda (Kumamoto Prefecture Museum Network Center), and Dr. Yasuro Kadono (Kobe University); they kindly permitted and assisted us in the examination of herbarium specimens. This work was supported by Grants in Aid for Scientific Research $(23701024,26350387)$ from the Japan Society for the Promotion of Science.

\section{Literature Cited}

Akasaka, M., N. Takamura, H. Mitsuhashi and Y. Kadono. 2010. Effects of land use on aquatic macrophyte diversity and water quality of ponds. Freshwater Biology 55: 909-922.

Chen, J. 1989. Systematic and Evolutionary Botanical Studies on Chinese Sagittaria. Wuhan University Press, Wuhan, 141 pp.

Chen, J.-K., X.-Z. Sun and H.-Q. Wang. 1984. New taxa of Sagittaria L. from Hubei. Bulletin of Botanical Research 4: 129 132.

Chen, L.-Y., J.-M. Chen, R. W. Gituru, T. D. Temame and Q.-F. Wang. 2012. Generic phylogeny and historical biogeography of Alismataceae, inferred from multiple DNA sequences. Molecular Phylogenetics and Evolution 63: 407-416.

Choi, H. K. 2000. Aquatic Vascular Plants. Korea Research Institute of Bioscience and Biotechnology (KRIBB), Daejeon, 220 pp. (in Korean)

Cronk, J. K. and M. S. Fennessy. 2001. Wetland Plants: Biology and Ecology. CRC Press, New York, 482 pp.

Du, G.-W., Q.-M. Yi and J.-K. Chen. 1998. Phylogenetic relationship of Chinese Sagittaria species (Alismataceae) based on AP-PCR analysis. Acta Phytotaxonomica Sinica 36: 216-221.

Frankham, R., J. D. Ballou and D. A. Bricoe. 2010. Introduction to Conservation Genetics. 2nd ed. Cambridge University Press, Cambridge, 644 pp.

Harada, I. 1956. Cytological studies in Helobiae, I. Chromosome idiograms and a list of chromosome numbers in seven families. Cytologia 21: 306-328.

Kadono, Y. 2014. A Field Guide to Aquatic Plants of Japan. Bunichi Sogo Shuppan, Tokyo, 326 pp. (in Japanese)

Keener, B. R. 2005. Molecular systematics and revision of the aquatic monocot genus Sagittaria (Alismataceae). Ph.D. dissertation, The University of Alabama, Tuscaloosa, AL, $336 \mathrm{pp}$.

Kim, H. and H. K. Choi. 2007. 188. Alismataceae Vent. In The Genera of Vascular Plants of Korea. Flora of Korea Editorial Committee (ed.), Academy Publishing, Seoul. Pp. 1070-1072.

Lee, T. B. 2003. Coloured Flora of Korea. Vol. I, II. Hayangmunsa, Seoul, Vol. 1, 914 pp, Vol. 2, 910 pp. (in Korean)

Lee, Y. N. 2007. New Flora of Korea, Vol. II. Kyo-Hak Publishing, Seoul, 885 pp. (in Korean) 
Liao, Y.-Y., A. W. Gichira, Q.-F. Wang and J. M. Chen. 2016. Molecular phylogeography of four endemic Sagittaria species (Alismataceae) in the Sino-Japanese Floristic Region of East Asia. Botanical Journal of Linnean Society 180: 6-20.

Makino, T. 1892. Note of Japanese plants, XV. Botanical Magazine, Tokyo 6: 45-56.

Makino, T. 1901. Observations on the flora of Japan. Botanical Magazine, Tokyo 15: 102-114.

Milligan, B. 1992. Plant DNA isolation. In Molecular Genetic Analysis of Populations: A Practical Approach. Hoelzel, A. R. (ed.), IRL Press, Oxford. Pp. 59-88.

Ministry of the Environment Government of Japan. 2015. Red Data Book 2014, Threatened Wildlife of Japan. Vol. 8: Vascular Plants. Gyousei, Tokyo, 646 pp. (in Japanese)

Oh, B. H., S. C. Ko, S. H. Kang, W. K. Back, K. O. Yoo, H. T. Im, C. K. Jang, K. Y. Chung, B. H. Choi, H. J. Choi, Y. M. Lee, C. H. Shin, K. Choi, J. S. Han, S. H. Park, H. J. Kim, G. S. Jang, J. C. Yang, S. Y. Jung, C. H. Lee, S. H. Oh and D. G. Jo. 2016. Distribution Maps of Vascular Plants in Korea. Korea National Arboretum, Pocheon, 809 pp.

Sculthorpe, C. D. 1967. The Biology of Aquatic Vascular Plants. Edward Arnold, London, 610 pp.

Shiga, T., S. Kato, M. Usuba, T. Yamanouchi, T. Kurazono, Y.
Hirasaswa and M. Yamazaki. 2017. Genetic identification of Sagittaria natans (Alismataceae) from Lake Yonuma (Iwate Prefecture) as a new locality in Japan. The Journal of Japanese Botany 92: 184-192.

Shin, H.-C., H.-C. Cha and H.-G. Choi. 1997. Taxonomic studies of the Korean Alismataceae: Numerical anaylses of Sagittaria sagittifolia-S. aginashi complex. Korean Journal of Plant Taxonomy 27: 471-480. (in Korean)

Tanaka, N. 2005. Typification of Dr. Makino's botanical names (1). The Journal of Japanese Botany 80: 22-26.

Wang, Q.-F. and J.-K. Chen. 1996. On Sagittaria tengtsungensis (Alismataceae), a species endemic to China. Acta Phytotaxonomica Sinica 34: 314-317.

Wang, Q., R. R. Haynes and C. B. Hellquist. 2010. Alismataceae. In Flora of China, Vol. 23 (Acoraceae through Cyperaceae). Wu, Z. Y., Raven, P. H. and D. Y. Hong (eds.), Science Press, Beijing and Missouri Botanical Garden Press, St. Louis, MO. Pp. 84-89.

White, T. J., T. Bruns, S. Lee and J. Taylor. 1990. Amplification and direct sequencing of fungal ribosomal RNA genes for phylogeneties. In PCR Protocols: A Guide to Methods and Applications. Innis, M. A., D. H. Gelfand, J. J. Sninsky and J. W. White (eds.), Academic Press, New York. Pp. 315-322. 